Earth Planet. Sci. Lett., (2019), https://doi.org/10.1016/j.epsl.2018.12.011

\title{
Subduction Initiation Terranes exposed at the front of a 2 Ma volcanically-active subduction zone
}

Patriat, Martin ${ }^{1}$, Falloon, Trevor ${ }^{2}$, Danyushevsky, Leonid ${ }^{2}$, Collot, Julien ${ }^{3}$, Jean, Marlon M. ${ }^{4,5}$, Hoernle, Kaj ${ }^{6}$, Hauff, Folkmar ${ }^{6}$, Maas, Roland ${ }^{7}$, Woodhead, Jon D. ${ }^{7}$, and Feig, Sandrin T. ${ }^{8}$

${ }^{1}$ Ifremer, Unité Géosciences Marines, 29280 Plouzané, France

${ }^{2}$ School of Natural Sciences - Earth Sciences, College of Sciences and Engineering, University of Tasmania, Hobart 7001, Australia

${ }^{3}$ Service Géologique de Nouvelle-Calédonie, DIMENC, 1 ter rue Unger, Vallée du Tir, BP465, 98845 Nouméa CEDEX, New Caledonia

${ }^{4}$ Earth and Environmental Sciences, University of Rochester, P.O. Box 270221, Rochester, NY 14627-0221, USA

${ }^{5}$ Leibniz Universität Hannover, Institut für Mineralogie, Callinstraße 3, 30167 Hannover, Germany

${ }^{6}$ GEOMAR Helmholtz Centre for Ocean Research Kiel, Wischhofstrasse 1-3, D-24148, Kiel, Germany

${ }^{7}$ School of Earth Sciences, University of Melbourne, Victoria 3010, Australia

${ }^{8}$ Central Science Laboratory, University of Tasmania, Hobart 7001, Australia

\begin{abstract}
The development of ideas leading to a greater understanding of subduction initiation is limited by the scarcity of present-day examples. Furthermore, the few examples identified so far unfortunately provide few insights into the nature of magmatism at the inception of subduction. Here we report new observations from the Matthew and Hunter $(\mathrm{M} \& \mathrm{H})$ subduction zone, a very young subduction zone located in the South-West Pacific. Tectonics of the area show it is younger than $2 \mathrm{Ma}$, making the $\mathrm{M} \& \mathrm{H}$ the youngest known volcanically-active subduction system and hence providing unique insights into the earliest stages of subduction initiation. Volcanism in this area comprises an exceptionally diverse range of contemporaneously erupting magma compositions which are spatially juxtaposed. $\mathrm{Pb}$ isotopic compositions and abundance of LILE and REE strongly suggest melting of upwelling asthenospheric mantle (Indian MORB) and subducted oceanic crust (Pacific MORB of the South Fiji Basin) and the mixing of these two components. Volcanism occurs much closer to the trench compared to volcanism in more mature subduction zones. We demonstrate that the M\&H subduction zone is a modern example of an immature subduction system at the stage of pre-arc, near-trench magmatism. It is not yet building an arc but what we propose to call a Subduction Initiation Terrane (SITER). Today, the proto-forearc of the M\&H subduction zone is a collage of these SITERs, coeval back-arc domains and remnants of pre-existing terranes including old Vitiaz Arc crust. The M\&H area represents a modern analog of a Supra Subduction Zone setting where potentially a majority of ophiolites have formed their crustal and lithospheric components. Present-day magmatism in the $\mathrm{M} \& \mathrm{H}$ area therefore provides clues to understanding unforeseen distribution of contrasted magmatic rock types in fossil forearcs, whether they are at the front of mature subduction zones or in ophiolites.
\end{abstract}




\section{Introduction}

The development of a subduction zone begins with the initiation of plate convergence and/or foundering of the subducted plate, followed by initiation of slab-dehydration processes and convection within the mantle wedge. Subduction-related partial melting and volcanism ensue, very close to the trench, producing new oceanic crust. We define this new crust as 'protoforearc' as it will eventually, as the arc matures, become the forearc of a mature subduction system with well-defined large trench parallel volcanoes (the volcanic front). This initial stage in the evolution of subduction zones is of short duration and modern analogues are therefore scarce; most active subduction zones are considered to be at a mature stage, with steady-state subduction having established active magmatism within a volcanic arc (Stern \& Bloomer, 1992; Stern, 2004; Gurnis et al., 2004; Ishizuka et al., 2011; Stern et al., 2012).

The composition of forearc crust is believed to differ from that of normal arc crust (Pearce et al., 1992; Bloomer et al., 1994; Reagan et al, 2017). Notably, sampled lavas from modern forearcs contain a highly diverse suite of spatially associated lavas, including boninites, island arc tholeiites and back-arc basin basalts (BABB). Their co-location is thought to reflect rapid temporal changes in the type of erupted magmas caused by mantle sources which become both chemically depleted and progressively more metasomatized, rather than subsequently juxtapositioned through tectonic processes (Pearce et al., 1984; Pearce et al., 1992; Bloomer et al., 1994; Reagan et al., 2010; Whattam \& Stern, 2011; Stern et al., 2012). In the case of the Izu-Bonin-Mariana (IBM) forearc, BABB-like volcanics are believed to have been erupted in the earliest stages of subduction initiation (Reagan et al., 2010). Compared to BABB erupting in the current Izu-Mariana back-arc spreading centers the BABB-like lavas from the forearc have lower $\mathrm{Ti} / \mathrm{V}$ and $\mathrm{Yb} / \mathrm{V}$ ratios and Reagan et al. (2010) called these lavas $\mathrm{FAB}$ (fore-arc basalts) and considered them to be a distinctive lava type erupted during subduction initiation. However, recent results from ocean drilling in rear-arc locations have recovered similar lavas to FAB (Arculus et al., 2015) suggesting that the term FAB should be used with caution. Several recently initiated subduction systems have been identified (e.g., Puysegur-Macquarie-Hjort, Mussau Trench; Gurnis et al., 2004) and this has contributed to improving our understanding of subduction initiation. However, none of these systems has reached the stage of significant magmatic activity, except for Pleistocene adakitic andesites on the Solander Islands in the Middle Miocene Puysegur subduction system (Sutherland et al., 2006; Mortimer et al., 2013). In the absence of pertinent modern analogues, understanding early-stage subduction zone volcanism is based on studies of forearc basements in the Izu Bonin Mariana (IBM) and Tonga Arcs, and of obducted remnants of forearc basements in some supra-subduction zone ophiolites (Bloomer et al., 1995; Shervais, 2001; Pearce, 2003; Whattam and Stern, 2011; Stern et al., 2012; Jean and Shervais, 2017). Here we describe a rare, very young (2 Ma) subduction zone where volcanic activity occurs very close to the trench and is characterized by an exceptionally wide compositional range. This range in composition includes boninites, low-Ti island arc tholeiites, BABB, adakite and a range of low to medium-K subduction related lavas. We demonstrate that it is a modern example of an immature subduction system at the stage of prearc, near-trench magmatism corresponding to the construction of a proto-forearc.

\section{The Matthew and Hunter area: A recently discovered infant subduction zone}

The Matthew and Hunter subduction system $(\mathrm{M} \& \mathrm{H})$ in the SW Pacific was recently proposed as a recently initiated subduction (Patriat et al., 2015). In this area, the trench and the arc present an abrupt change in direction from NW-SE to E-W. Historically, this region was considered the southern termination of the New Hebrides subduction zone and not an independent, newly 
initiated subduction system. Tectonics of the $\mathrm{M} \& \mathrm{H}$ area have been interpreted as corresponding to a Subduction-Transform Edge Propagator (STEP) fault at the end of the New Hebrides subduction (Monzier et al., 1984; Govers \& Wortel, 2005; Lister et al., 2012). However, GPS data show that the Matthew and Hunter Islands are moving south at a speed of $4.8 \mathrm{~cm} / \mathrm{y}$ relative to north-directed subduction of the South Fiji Basin, a part of the Australian Plate (Fig. 1; Calmant et al., 2003).

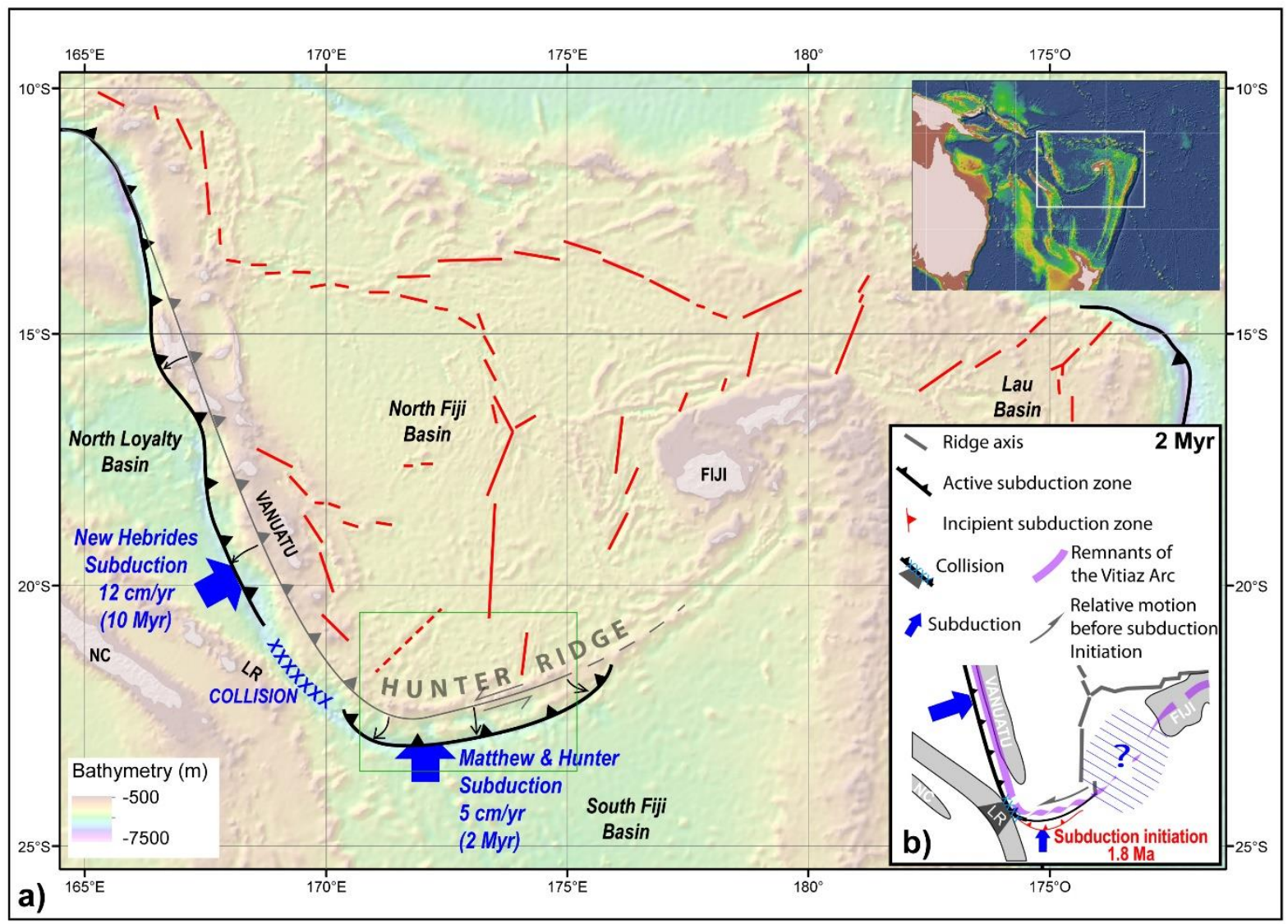

Figure 1: A) Simplified present-day geodynamic map of the New Hebrides and Matthew-Hunter subduction systems (modern trenches shown in black). Inferred location of the New Hebrides subduction and its termination as a STEP fault before 2 Ma shown in light grey. Inset map shows the regional bathymetry. B) Schematic evolution of the North Fiji Basin when the system shifted from a STEP fault to subduction initiation at 2 Ma (after Patriat et al., 2015). LR, Loyalty Ridge; NC, New Caledonia. Green box: area of figure 2.

Combined with new data collected during three voyages of the RV Southern Surveyor (20042009) and with detailed analysis of seismicity, the GPS kinematic evidence led to reinterpreting the tectonic setting (Patriat et al., 2015). Miocene SW rotation of the New Hebrides arc-trench system was slowed by a collision of its southern end with the Loyalty Ridge. This kinematic change induced deformation of the upper plate (North Fiji Basin) and initiated a new and independent N-S subduction system east of the collision (Monzier et al., 1984, Patriat et al., 2015). Thus, the area formerly dominated by a Miocene STEP fault is now a distinct new WSWENE subduction system related to northward subduction (Fig. 1).

The geomorphology of the M\&H region (Fig. 2) reflects this tectonic setting. The Hunter Ridge runs parallel to a trench up to $7300 \mathrm{~m}$ deep located $80 \mathrm{~km}$ to the south. The ridge is characterized by shallow bathymetry and an alignment of volcanoes and elevated blocks. Satellite bathymetry of the largely unsurveyed area between the ridge and trench indicates an average depth of $\sim 4000$ $\mathrm{m}$. This area is cut by NNW-SSE grabens reaching $5800 \mathrm{~m}$ in depth (Fig. 2). The N-S Eissen Spreading Center propagates southward from the North Fiji Basin into the Hunter Ridge (Maillet et al., 1989; Patriat et al., 2015). At the transition between the Hunter Ridge and the Eissen Spreading Center is the Monzier Rift, a WSW-ENE flat valley intruded by small 
volcanic elevations and separated from its shoulders by steep fault scarps. The rift hosts small seamounts and volcanic ridges arranged en-echelon along the axis of the rift and elongated in a NNE direction. A linear and continuous E-W sinistral strike slip fault connects the southwestern tip of the Monzier Rift to Hunter Island. The Monzier Rift is interpreted as a graben opening synchronously with the Eissen Spreading Centre in an area of sinistral transtension (Fig. 2).

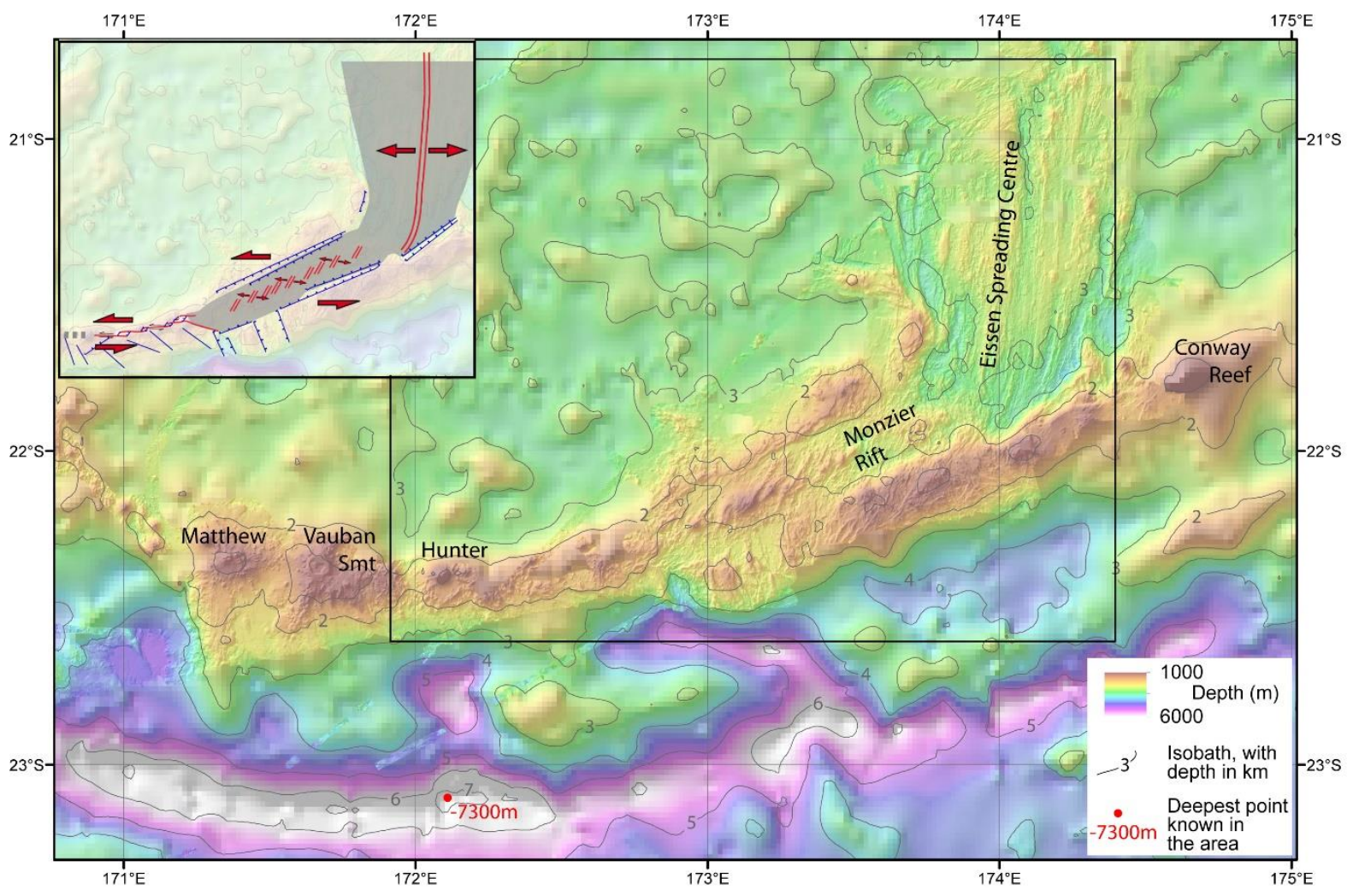

Figure 2: Morphology of the Hunter Ridge (multibeam and satellite bathymetry). Black lines are $1000 \mathrm{~m}$ isobaths based on satellite bathymetry. Inset shows structural interpretation after Patriat et al. (2015). Although most of the area between the Hunter Ridge and the trench is interpreted as being younger than $2 \mathrm{Ma}$, only the area in grey (inset) can be demonstrated to be of such a young age, see text.

The chronology of the tectonic elements that make up the M\&H subduction system must postdate initiation of Pleistocene deformation in the supra-subduction plate and the switch from wrenching along a STEP fault to N-S convergence between the Hunter Ridge and the South Fiji Basin at ca. 2 Ma. This is consistent with interpretation of magnetic anomalies which shows that opening of the Eissen Spreading Ridge began 1.8 Ma ago (Patriat et al., 2015). The Monzier rift is of the same age (Fig. 2) but opened within elevated blocks probably inherited from the $\sim 10$ Ma Vitiaz Arc (Danyushevsky et al., 2006; Patriat et al., 2015). While unmapped, the area between the Hunter Ridge and the trench also has a probable Pleistocene or younger age, based on its thin pelagic sediment cover (two-way travel times $<0.15 \mathrm{sec}$ ) and the biostratigraphy of lithified sediments dredged with basement samples (Puschin, 1990). By inference, the M\&H subduction zone is also younger than $2 \mathrm{Ma}$ (Patriat et al., 2015). This is supported indirectly by the size of the slab and by the timing of collision between the Vanuatu Arc and the Loyalty Ridge (Maillet et al., 1989; Monzier et al., 1993). Finally, the geomorphology of the dredge site locations (see Supplementary Information) constrains the age of lavas sampled within the Monzier Rift and along the Eissen Spreading Centre as $<2 \mathrm{Ma}$, as they cannot be older than the age of the crust $(\leq 2 \mathrm{Ma})$ in these locations. The $\mathrm{M} \& \mathrm{H}$ is thus the youngest known volcanically-active subduction system. 


\section{Geochemistry of M\&H lavas}

\subsection{Sampling}

This study is based on results from 5 voyages to the southern termination of the Vanuatu Trench-North Fiji Basin-Hunter Ridge area between 1990-2009. These voyages include cruise 17 of the RV Akademik Alexander Nesmeyanov in 1990 (Pushchin 1990; Sigurdsson et al., 1993), the 1994 'ProFeTi' cruise of the RV Alis (Fleutelot et al., 2005; Durance et al., 2012) and three voyages of the RV Southern Surveyor in 2004, 2006 and 2009 (Patriat et al., 2015). In Tables S1 and S2 we present representative geochemical data for the RV Southern Surveyor and RV Akademik Nesmeyanov voyages respectively. Sampling was conducted by rock dredging except for the sampling of the Eissen Spreading Center, which was done by wax coring techniques (Supplementary Information figure S1).

Analytical techniques are detailed in Supplementary Information.

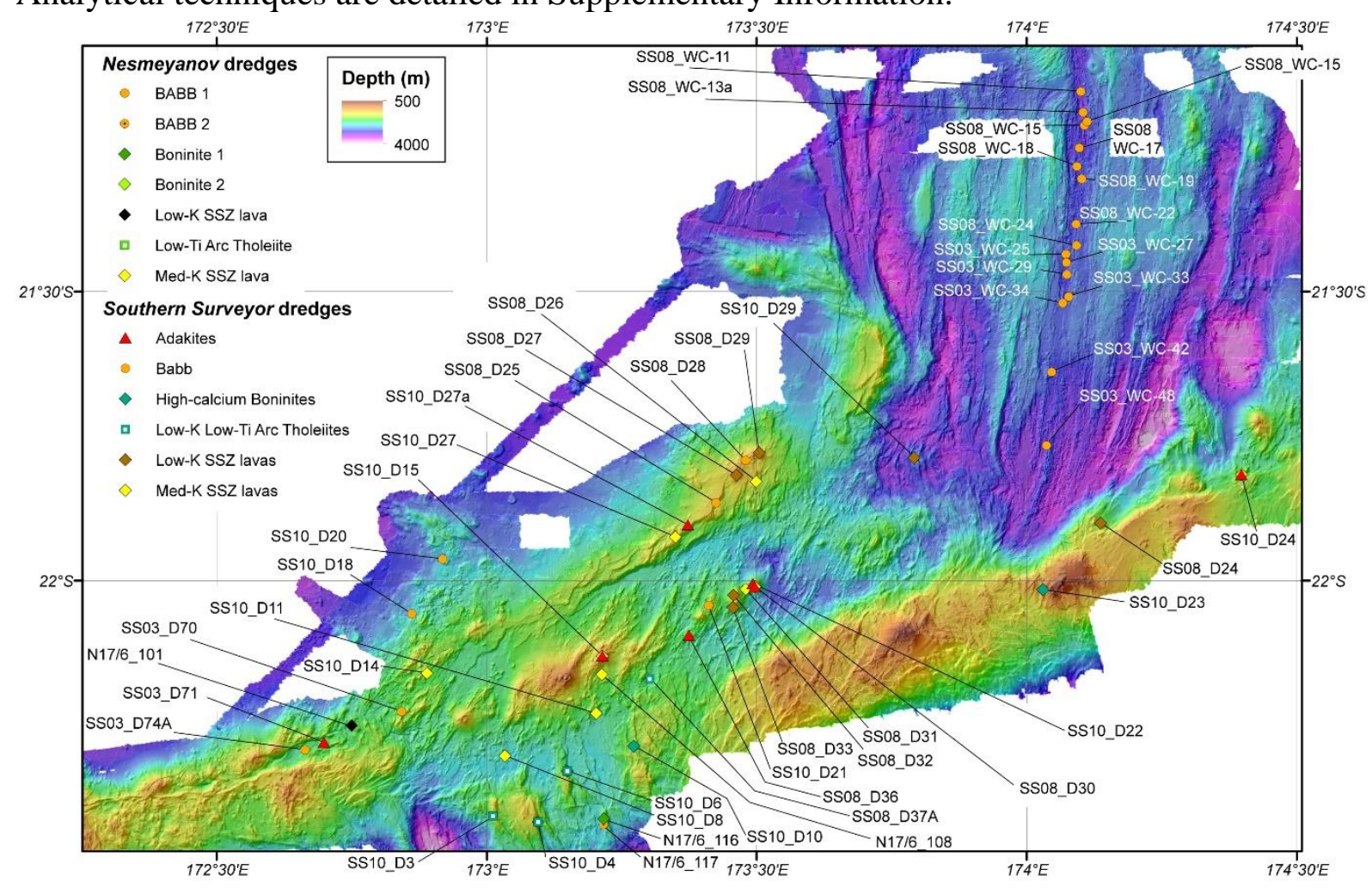

Figure 3: Morphological map (multibeam and satellite bathymetry) showing the locations of dredges from which representative samples are presented in this paper (Supplementary Information, Tables S1 and S2). Each dredge station in figure 3 is given a color-coded symbol to highlight the nature of the most significant or representative magma type recovered (see legend). Note that in a few cases dredge stations recovered more than one magma type. However, for clarity and to demonstrate the overall spatial range of magma types recovered in the study area, each dredge station has a single magma type displayed (e.g. SS08_D33 in addition to low-K, SSZ lavas also recovered adakite; SS10_D15 also recovered Med-K SSZ lavas. As discussed in the text, this diversity reflects mixing processes occurring during subduction initiation). See Supplementary Information figure S1, for a more complete map, with the location of all dredges used in this study.

In the following figures, we distinguish data obtained from the Southern Surveyor voyages and those of the Nesmeyanov voyage. This is because the level of accuracy and the confidence on the position of dredge operations were not comparable. Sampling during the Southern Surveyor voyages was undertaken with such good multibeam bathymetry that it was clearly possible to identify scarps cutting the old Hunter Ridge basement versus young volcanic features associated with the Eissen Spreading Center and the Monzier Rift. The majority of Nesmeyanov 
dredges however occurred in deeper waters on the landward trench slope, and their position was decided using only single line bathymetric profiles (Pushchin 1990). Thus it is not certain whether young or old crustal components were sampled. Notably, although the majority of the low-Ti arc tholeiites and boninites sampled by the Nesmeyanov are identical to those sampled on well-located scarps on the Hunter Ridge and are mostly likely old Hunter Ridge basement, in the absence of rock age it is not possible to be absolutely confident that some of these lavas are not contemporaneous with current volcanism in the Monzier Rift and Eissen Spreading Center.

\subsection{Results}

\subsubsection{Exceptionally diverse range of lava compositions}

Dredging and wax-coring of the Monzier Rift (MR) and Eissen Spreading Center (ESC) by the Australian National Marine Facility's RV Southern Surveyor (voyages SS10/04, SS08/06 and SS03/09) recovered an exceptionally diverse range of lava compositions (Fig. 3). The compositional diversity of these lavas is illustrated in figure 4. Low-K compositions from the ESC and MR have V-Ti contents, and Ti/V and $\mathrm{Zr} / \mathrm{Sm}$ values which overlap with those in low$\mathrm{K}$ forearc basalt $(\mathrm{FAB})$ suites inferred to have formed during the initial stages of subduction in the Izu-Bonin-Mariana (IBM) subduction system ( 50-52 Ma, Ishizuka et al., 2006; 2011; Reagan et al., 2010; 2013). Boninites are a prominent component in the Hunter Ridge although their ages are poorly constrained: high-Ca boninites were dredged from high blocks of the Hunter Ridge which could be relics of the dismembered $10 \mathrm{Ma}$ Vitiaz Arc (Danyushevsky et al., 2006; Patriat et al., 2015) while more depleted boninites collected closer to the trench (Sigurdsson et al., 1993) may be younger. The boninites have the lowest $\mathrm{Ti}, \mathrm{Ti} / \mathrm{V}$ and high $\mathrm{Zr} / \mathrm{Sm}$.
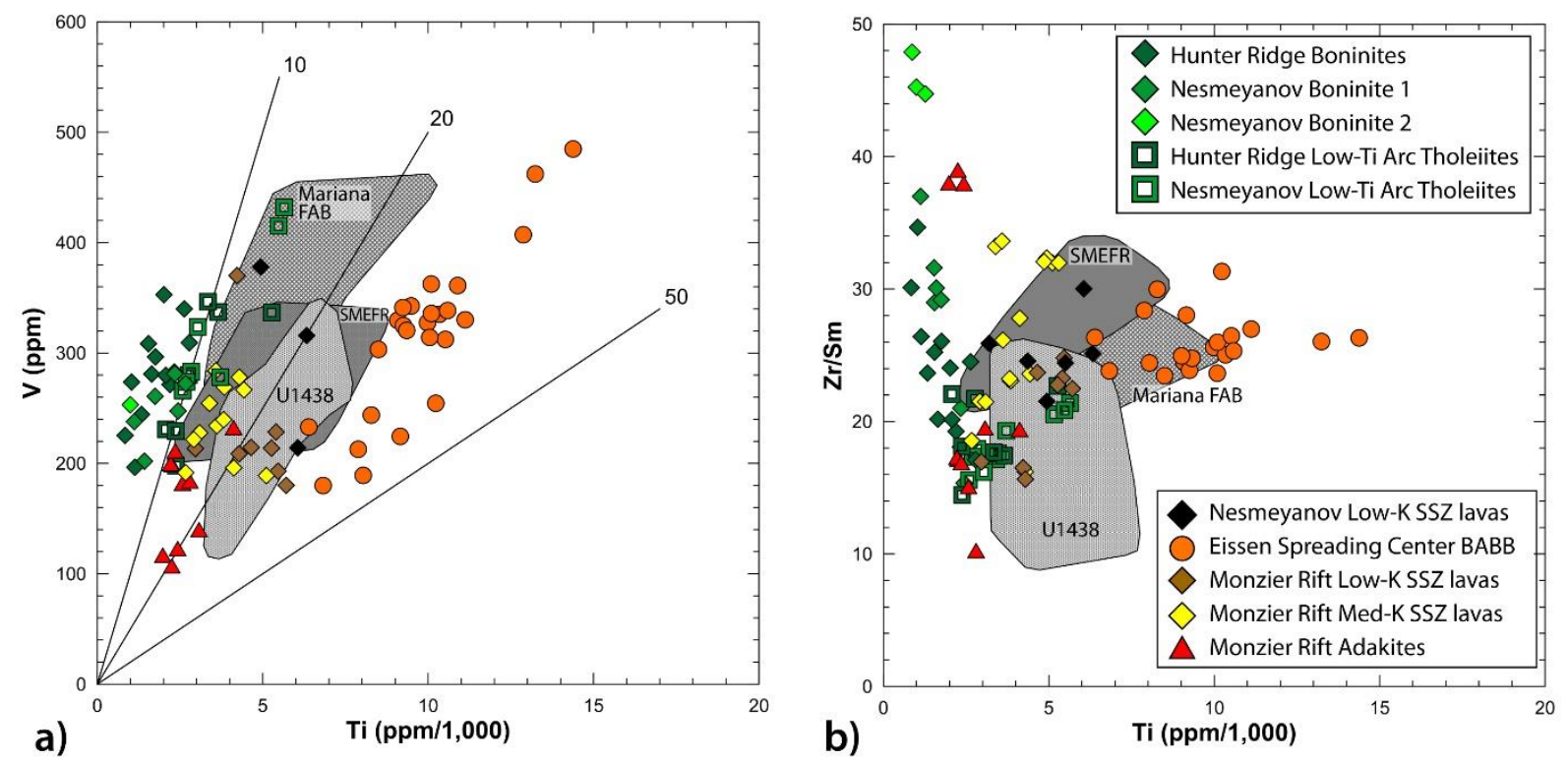

Figure 4: Chemical variations in M\&H lavas (Table S1 and S2), compared to composition of forearc basalts (FAB) from the Izu-Bonin-Mariana subduction system (Mariana FAB - Reagan et al., 2010; U1438 - Hickey-Vargas et al., 2018, Ishizuka et al., 2018) and recent lavas erupted in rifts on the Southern Mariana Trench slope (SEMFR Ribeiro et al., 2013a). A) V vs Ti (with lines of constant Ti/V marked 10, 20 and 50 (Shervais, 1982)) and B) $\mathrm{Zr} / \mathrm{Sm}$ vs Ti. Classification as low- and med-K after Peccerillo and Taylor (1976). Note that some of the overlap in composition could be due to fractionation and accumulation of phenocryst phases. The average $\mathrm{MgO}$ content for Low-K SSZ lavas from the Monzier Rift is $9.6 \mathrm{wt} \% \mathrm{MgO}$ and BABB from the Eissen Spreading Center is 7.0 wt $\% \mathrm{MgO}$, comparing favorably with averages for FAB from the IBM (6.92 wt\% MgO, Reagan et al., 2010) and IODP site U1438 (8.58 wt\% MgO, Ishizuka et al., 2018). This suggests that the effects of fractionation and accumulation of phenocryst phases will not be a significant factor in the relative positions of different lava suites 
in figure 4. Although correction to a constant $\mathrm{MgO}$ content (e,g, $\mathrm{TiO}_{2}$ contents at $\mathrm{MgO}$ of $8 \mathrm{wt} \%$, $\mathrm{Ti} 8$ ) would be more accurate, such calculations can potentially introduce errors (e.g. Kelemen et al., 2003).

Boninites recovered by $R / V$ Nesmeyanov (Sigurdsson et al., 1993) are divided into groups 1 or 2 (see text for explanations). Boninite Group 2 samples are characterized by relatively high $\mathrm{Zr} / \mathrm{Sm}(>45)$.

The M\&H subduction system also produced adakites. Adakites are a subduction-related magmatic rock suite that has chemical features atypical of volcanic arcs but consistent with melting of subducted oceanic crust. They are classified mainly on the basis of trace element abundances and ratios, showing notably enrichment in $\mathrm{Sr}, \mathrm{Na}$, and Eu but depletion in $\mathrm{Y}$ and the HREE (see Danyushevsky et al., 2008 for detailed discussion and references concerning adakites and their definition and classification). In the $\mathrm{M} \& \mathrm{H}$ area both low and high-silica adakites are present. Compared to other magma types present in the $\mathrm{M} \& \mathrm{H}$ area, adakites have low Ti contents (Fig. 4) combined with high La/Yb values (Fig. 5b).

A more detailed petrological study of the large range of volcanic rocks recovered from this area will be presented elsewhere. However, physical and geological evidence indicates that these diverse lavas are <2 Ma old, broadly coeval and spatially juxtaposed (Fig. 3). The purpose here is to highlight these associations. In particular, three remarkable juxtapositions of rock types are found, $\mathrm{BABB}$ and Adakite, $\mathrm{BABB}$ and Boninite 1 and low-K SSZ lavas and boninite 2 . 

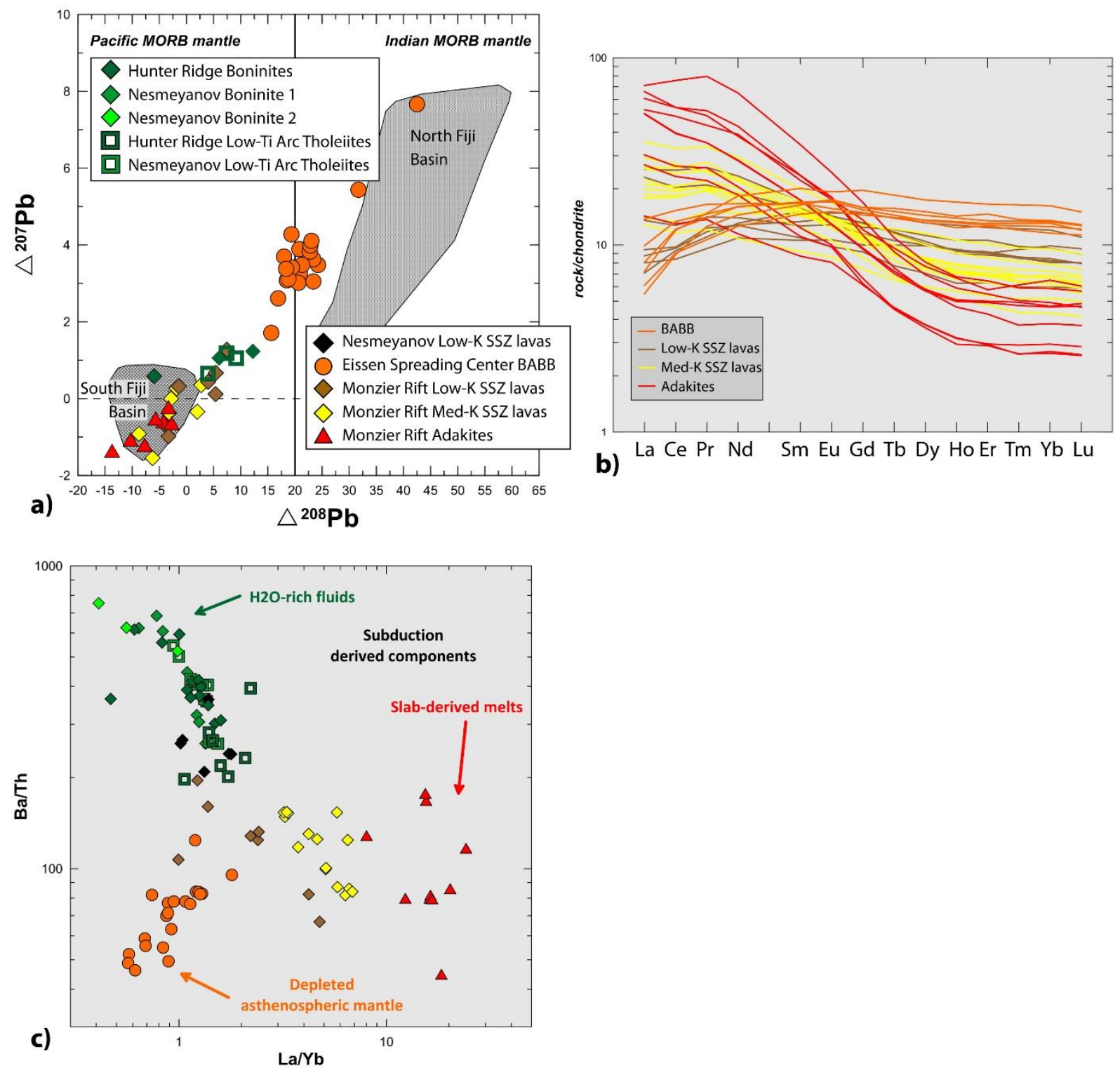

Figure 5: A) $\Delta^{207} \mathrm{~Pb}$ vs $\Delta^{208} \mathrm{~Pb}$ of H\&M lavas (Table S1) compared to South Fiji Basin oceanic crust (Gill, 1987; Pearce et al., 2007) and North Fiji Basin spreading centers (Fleutelot et al., 2005; Pearce et al., 2007). $\Delta^{207} \mathrm{~Pb}$ and $\Delta^{208} \mathrm{~Pb}$ are deviations from the 'Northern Hemispheric Reference Line' (Hart, 1984). A $\Delta^{208} \mathrm{~Pb}=20$ distinguishes Pacific and Indian MORB mantle sources (Hanan et al., 2004). The linear variation in $\Delta^{207} \mathrm{~Pb}-\Delta^{208} \mathrm{~Pb}$ suggests mixing between an Indian MORB mantle component, represented by the Eissen Spreading Center BABB, and a Pacific MORB mantle component, represented by the adakites from the Monzier Rift.

B) Chondrite-normalized rare earth element (REE) patterns of Monzier Rift lavas. In general, REE patterns and REE abundances are consistent with mixing between adakite and BABB lavas (see figure 5a) if phenocryst accumulation ( $\mathrm{MgO} 5-20 \mathrm{wt} \%$ ) is taken into account. The plotted data include whole rocks and glasses (Table S1). Chondritic REE abundances from Taylor and Gorton (1977). C) Ba/Th vs La/Yb values for young M\&H lavas, symbols as in figure 5a. The observed patterns suggest mixing of a depleted asthenospheric mantle component derived from the Eissen Spreading Center and subduction components from the subducting South Fiji Basin crust.

\subsubsection{The close association of $\mathrm{BABB}$ and Adakite}

In two locations within the Monzier Rift, a tectonic graben < 2 Ma old (Patriat et al., 2015), we discovered a very close spatial association $(<4 \mathrm{~km})$ of depleted BABB and adakite lavas from young volcanic cones. 
The first location occurs at the western end of the propagating Monzier Rift, where SS03/09 D74A sampled depleted Babb and SS03/09 D71 sampled adakite (Fig. 4). Both dredges D74A and D71 sampled small volcanic cones within the active rift and recovered very fresh glassy volcanics consistent with a very young age and contemporaneous eruption (Supplementary Information figure S2). Adakite composition D71-9 (Table S1) has very low $\mathrm{TiO}_{2}(0.39 \mathrm{wt} \%)$ and is picritic in composition (15.13 wt $\left.\% \mathrm{MgO}\right)$ reflecting accumulation of abundant olivine and clinopyroxene phenocrysts and is highly vesicular indicating a significant volatile content degassing on eruption (Supplementary Information figure S4a). In contrast BABB composition D74A-3 has MORB like $\mathrm{TiO}_{2}(1.34 \mathrm{wt} \%)$ and is basaltic in composition $(9.50 \mathrm{wt} \% \mathrm{MgO})$ reflecting small amounts of olivine phenocrysts (+ minor plagioclase) and is non-vesicular indicating very low volatile content on eruption (Supplementary Information figure S3). As can be seen from figure 6a, samples D71-9 and D74A-3 have strongly contrasting abundances of trace elements reflecting very different source origins and petrogenetic processes. Sample D74A-3 shows no evidence of a subduction component and has a trace element abundance pattern identical with a depleted asthenospheric MORB-like melt, whereas sample D71-9 has a strong subduction component with very high enrichments in LILE, LREE and depletion in HFSE and HREE. It also has a very high $\mathrm{Sr} / \mathrm{Y}$ value of 80 due to high $\mathrm{Sr}$ contents ( $800 \mathrm{ppm})$ and low Y (10 ppm), a characteristic of adakite magmas.
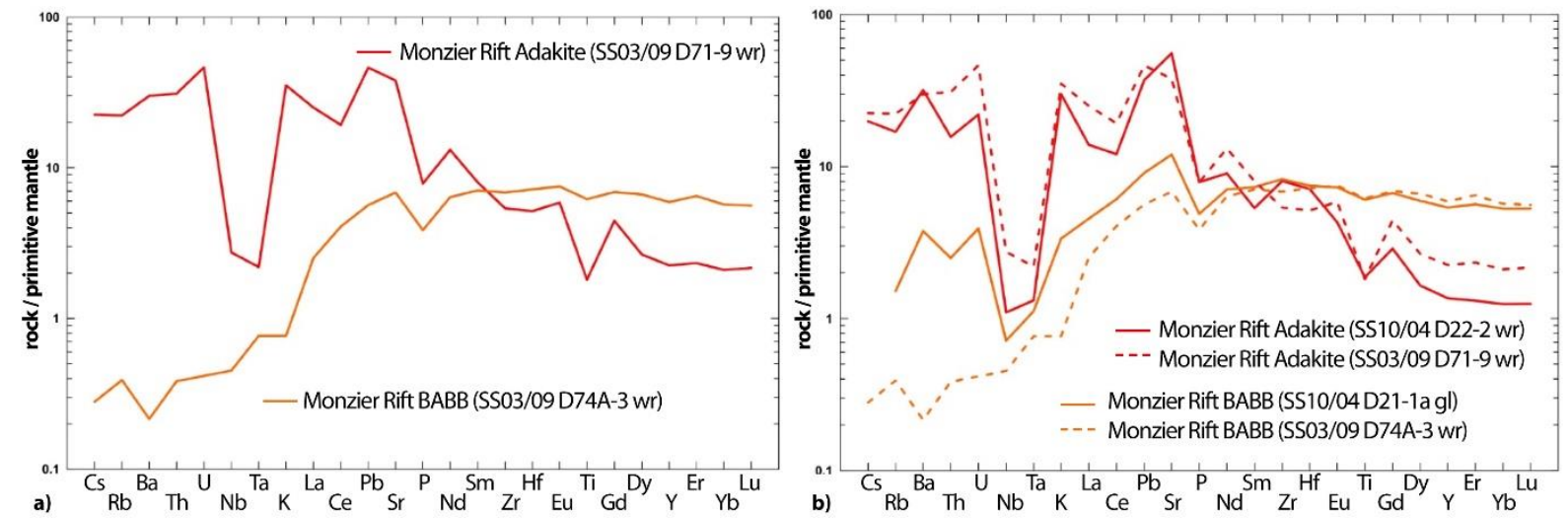

Figure 6: Primitive mantle normalized trace element abundance patterns (Table S1). Primitive mantle normalizing values from Sun and McDonough (1989). Wr: whole rock, gl: glass. A) Adakite SS03/09 D71-9 and BABB SS03/09 D74A-3. Note that for sample D74A-3 U was not plotted due to minor seafloor alteration. B) Adakite SS10/04 D22-2 and BABB SS010/04 D21-1a. (Table S1).

The second location occurs in the center of the main part of the Monzier Rift where dredge SS10/04 D21 recovered fresh basaltic pillow lavas and $\sim 10 \mathrm{~km}$ away dredge SS10/04 D22 sampled highly phyric (oliv opx cpx plag amph) andesitic compositions from a young volcanic cone $\sim 600 \mathrm{~m}$ high (Fig. 3). Again the freshness of the samples is consistent with a very young age and contemporaneous eruption within the Monzier Rift. The analyzed glass from D21 (SS10/04 D21-1a, Table S1) has MORB-like $\mathrm{TiO}_{2}(1.32 \mathrm{wt} \%)$ and is basaltic in composition (7.63 wt\% MgO). The analyzed dredge D22 adakite whole rock composition (SS10/04 D22-2, Table S1) has very low $\mathrm{TiO}_{2}(0.41 \mathrm{wt} \%)$ at a similar $\mathrm{MgO}$ content (7.37 $\mathrm{wt} \%$ ). Like BABB from dredge D74A and adakite from dredge D71, both BABB from dredge D21 and adakite from dredge D22 have strongly contrasting trace element abundance patterns. However in this case the BABB composition shows a significant contribution of a subduction-related component. This can be seen from elevated abundances of LILE in glass D21-1a relative to the pattern of sample D74A-3 (Fig. 6b). Both the BABB compositions have $\mathrm{Pb}$ isotopic compositions falling in the range of wax-coring samples from the Eissen Spreading Center indicating an Indian MORB-like mantle derivation, whereas the adakite compositions have $\mathrm{Pb}$ isotope compositions overlapping the range of basalts from the South 
Fiji Basin crust (see figure 5a). This result strongly suggests that we have contemporaneous melting of upwelling asthenospheric mantle (Indian MORB) and subducted oceanic crust (Pacific MORB of the South Fiji Basin). We believe the mixing of these two components may explain the range of compositions seen in the other SSZ lavas as suggested by their intermediate location in the 3 diagrams of figure 4 . A detailed examination of this hypothesis and implications will be presented elsewhere.

\subsubsection{The close association of $B A B B$ and boninite 1}

As previously mentioned, the Nesmeyanov voyage sampled deeper areas of the landward slope of the trench (Supplementary Information figure S1). Several of these dredges sampled material from deep graben-like structures on the landward slope. In particular dredges D116 and D117 are of interest as they are only $2 \mathrm{~km}$ apart and sampled BABB (D117) and boninites (D116). As seen in figure 7a the two BABB glass types identified by Sigurdsson et al. (1993) match the compositions of BABB erupted at the Eissen Spreading Center (BABB 1, Fig. 7a) and within the Monzier rift (BABB 2, Fig. 7a). This result strongly suggests that BABB magmas are currently erupting at relatively deeper water depths $(4640 \mathrm{~m})$ on the landward trench forming new oceanic crust. Dredge D116, in contrast, recovered boninites at slightly deeper water depths $(5200 \mathrm{~m})$ very close $(2 \mathrm{~km})$ to the location of dredge D117. As can be seen on figure $8 \mathrm{a}$ the dredge D116 boninites are very similar to boninites recovered from scarps of the tectonically dismembered Hunter Ridge. The significance of this result is difficult to resolve in the absence of age dating and detailed bathymetric mapping. Two possibilities include dredge D116 sampled contemporaneous boninite magmatism associated with BABB and subduction initiation or dredge D116 has sampled Hunter Ridge boninitic basement which has been incorporated within new oceanic crust being formed at these depths.
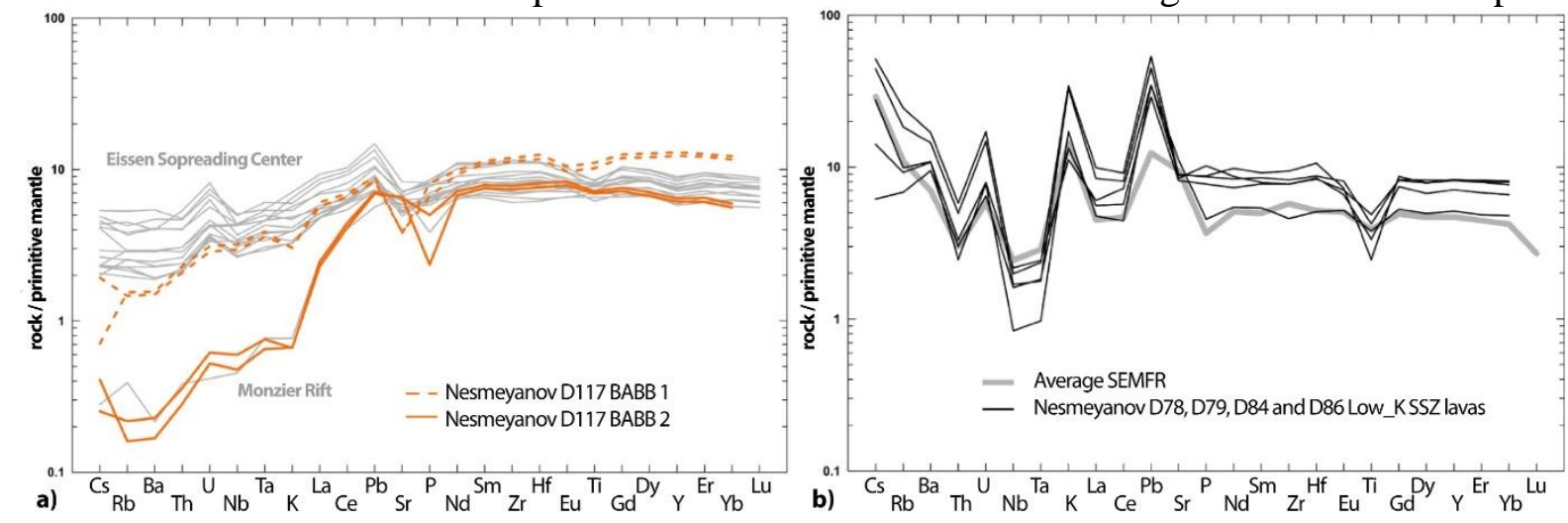

Figure 7: Primitive mantle normalized trace element abundance patterns. Primitive mantle normalizing values from Sun and McDonough (1989). A) BABB 1 and BABB 2 recovered by the Nesmeyanov at dredge D117 (Table S2) compared to the range of representative BABB glasses from the Eissen Spreading Center (Table S1) and depleted BABB of dredge D74A-3 from the Monzier Rift. B) Low-K SSZ lavas recovered by the Nesmeyanov from the landward trench slope within the study area compared with the average low-K SSZ lava recovered from the SEMFR (Ribeiro et al., 2013b). 

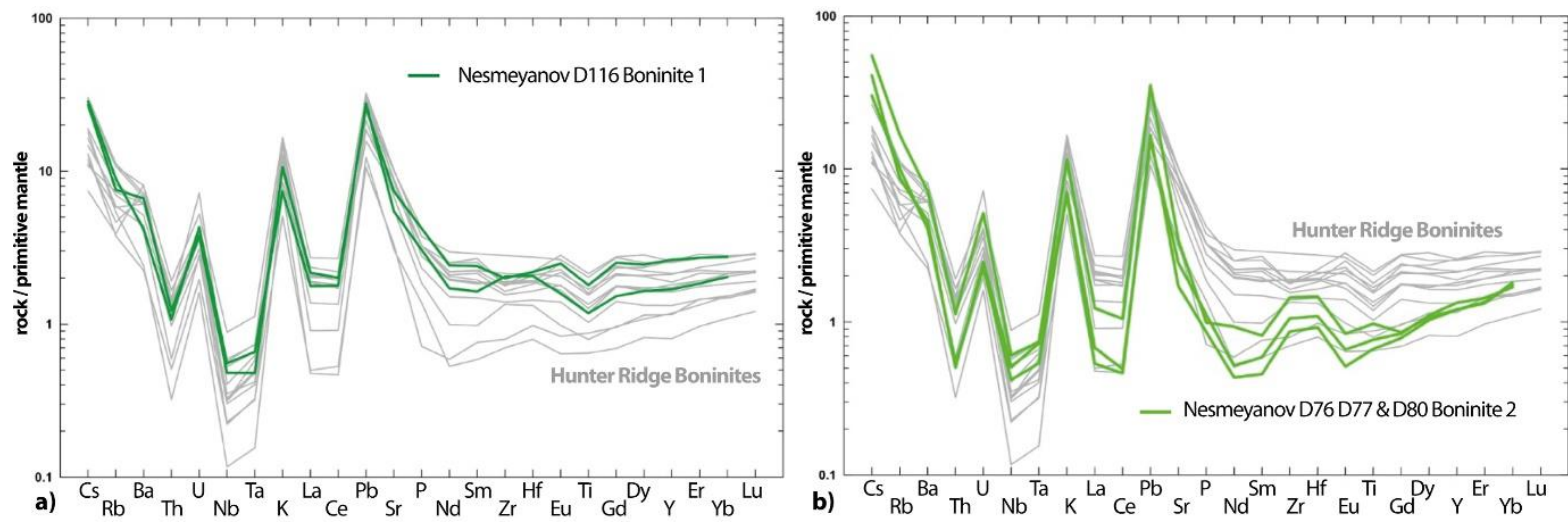

Figure 8: Boninite compositions recovered by the Nesmeyanov (Table S2) compared to the range in representative boninite compositions recovered from well-located scarps on the Hunter Ridge within the study area (Table S1). Primitive mantle normalizing values from Sun and McDonough (1989). A) Boninite 1. B) Boninite 2.

\subsubsection{The close association of low-K SSZ lavas and boninite 2}

To the west of dredges D116 and D117, the Nesmayenov voyage recovered a distinctive suite of low-K SSZ lavas at dredges D84, 86, 78 and 79 at water depths between 3030-4965m (Fig. $7 \mathrm{~b}$ and Supplementary Information figure S1, Table S1 and S2). Boninites were also recovered together with these low-K SSZ lavas at dredges D77 and D78. The location of these dredges coincides with a rift-like structure cutting the older crust (which forms local topographic highs and ridges). The low-K SSZ lavas consist of rhyolites at dredges D84 and D87 and basaltic andesites and andesites at dredges D78 and D79. As can be seen in Table S2, the low-K SSZ lavas have glass major element chemistry identical to Pliocene aged (2.73.8Ma) lavas recovered from the Southern Mariana landward trench slope (Ribeiro et al., 2013a, b) and recently erupted lavas near the Challenger Deep at 5.5-6km depth (Stern et al., 2014). These lavas from the Southern Mariana area erupt in rifts (Southeastern Mariana Rifts -SEMFR, Ribeiro et al., 2013b) and form new oceanic crust very close to the trench. The lavas are BABB-like in their $\mathrm{TiO}_{2}$ contents but are unlike most BABB and MORB lavas in having relatively high $\mathrm{SiO}_{2}$, and $\mathrm{Na}_{2} \mathrm{O}$ contents and a strong subduction derived slab component (Fig. 7b; Ribeiro et al., 2013a, b). Although we do not as yet have age dating for these lavas - the similarities between the SEMFR lavas geochemistry and tectonic setting and the Nesmeyanov low-K lavas strongly suggests the possibility of active to recent volcanism. The boninites were recovered along with the low-K SSZ lavas and also at dredges D76, 77 and D80 (Supplementary Information figure S1, Table S2). The majority of the boninites are similar to those recovered from well-located scarps on the Hunter Ridge (boninite 1) and could either represent old basement material or in view of their close association with the low-K SSZ lavas, relatively recent magmatism associated with subduction initiation. Of interest is the recovery in the deepest dredge D76 (6240m) and also dredges D77 and D80 of a distinct boninite lava not previously sampled from well-located scarps on the old Hunter Ridge basement (boninite 2, Fig. 8b). These boninite lavas are distinctive due to their relatively high $\mathrm{Zr} / \mathrm{Sm}$ values compared to boninites recovered from the Hunter Ridge (Fig. $3 b$ ). As can be seen on figure 8 b, the enrichment in $\mathrm{Zr}$, as well as Hf, produces a distinctive positive $\mathrm{Zr}$-Hf anomaly relative to REE in the normalized abundance patterns. Such $\mathrm{Zr}$ and Hf enriched boninites are also present in the IBM system starting c. 2 Ma after subduction initiation (Pearce et al. 1992; Reagan et al., 2017). Future work - especially age dating - is required in order to fully understand the geodynamic significance of these boninites. 


\section{Discussion}

\subsection{A unique magmatic setting?}

Until the $\mathrm{M} \& \mathrm{H}$ area was recognized as a distinct subduction zone accommodating N-S convergence (Patriat et al., 2015), the trench south of the Hunter Ridge was interpreted as a transform boundary (the Hunter Fracture Zone; Monzier et al., 1984; Maillet et al., 1989) at the southern termination of the New Hebrides Subduction Zone. The large diversity in lava compositions sampled in this area, particularly the presence of boninites, was then attributed to the peculiar regional geodynamic context, most often summarized as the intersection of a spreading ridge and a volcanic arc (Crawford et al., 1989; Monzier et al., 1993; Sigurdsson et al., 1993; Deschamps and Lallemand, 2003). This tectonic setting was suggested to be capable of producing at least two types of melts: one resulting from adiabatic decompression of MORBlike mantle and the other resulting from melting of the metasomatized mantle wedge. Intrusion of a MORB mantle diapir into a metasomatized supra-subduction zone mantle would also provide an explanation for the high temperatures required to cause melting in the subducting slab and high melting rates of the mantle. In other models, a toroidal flow of hot asthenospheric mantle into the metasomatized mantle wedge at the southern end of the New Hebrides subduction zone is invoked (Durance et al., 2012). Lallemand (2016) suggests that a mantle plume could explain the improbable intersection of a spreading ridge with a volcanic arc and provide an additional source of heat to produce significant amounts of boninitic magma.

The northern termination of the Tonga Trench and the southern termination of the Mariana Trench are also two subduction edge areas whose tectonic setting and the large variety of volcanic rocks resemble the $\mathrm{M} \& \mathrm{H}$ area. As a matter of fact, the North Lau Basin have boninites and one reported adakite composition (Falloon et al., 2008), and the South Mariana has subduction related low-K lavas but no calc-alkaline lavas and no adakites (Ribeiro et al., 2013b). However, these two areas do not produce primitive calc-alkaline magmas or an intimate temporal/spatial association of depleted asthenospheric MORB-like magmas and primitive adakites. Only in the $\mathrm{M} \& \mathrm{H}$ area do we see these two distinct components, an asthenospheric derived MORB-like decompression melt and a slab melt, and their mixing products, including adakites.

\subsection{Is near-trench magmatism of the Matthew and Hunter area a feature of subduction initiation?}

As shown above, the M\&H Subduction System has some unusual features. Although its exact location is unclear, the $\mathrm{M} \& \mathrm{H}$ volcanic axis (i.e. the Matthew, Hunter, Vauban and other volcanic centers of the Hunter Ridge) is $<100 \mathrm{~km}$ from the subduction trench, among the shortest arc-volcano-to-trench distance globally (Syracuse and Abers (2006, also see Supplementary Information figure S4). Another subduction system where volcanism also occurred close to the trench is the Bonin-Ogasawara Ridge, part of the Izu-Bonin forearc that has been recognized, on the basis of age, geochemistry and melting processes, as being formed during subduction infancy (Ishizuka et al., 2006).

The great diversity in primitive lava compositions, including adakites (Figs. 4 \& 5), associated with this particular geodynamic setting is proposed herein as a characteristic feature of subduction initiation. These proposed features are consistent with both tectonic and petrological data from the Hunter Ridge and other similar settings (e.g., Southern New Zealand; Reay \& Parkinson, 1997; Sutherland et al., 2006; Kadavu, Fiji, Danyushevsky et al., 2008; Bonin forearc, Li et al., 2013).

One final argument in support of $\mathrm{M} \& \mathrm{H}$ being a young subduction zone is the available age information for the area between the Hunter Ridge and the inner slope of the E-W-directed 
trench. Maturation of a subduction zone to the point of stable magmatism and establishment of an extensive volcanic arc involves development of mantle convection and dehydration processes in the subducted lithosphere, and this takes several millions years (Mitchell et al., 1992; Ishizuka et al., 2011; 2018). This length of time was not available in the case of M\&H which thus cannot be a mature arc.

In summary, the $\mathrm{M} \& \mathrm{H}$ subduction zone is an immature system which has only evolved to a first stage of subduction related magmatism. The geochemical, geodynamic, chronological and geomorphological features of the area are consistent with those of an infant subduction zone showing pre-arc near-trench magmatism.

\subsection{How is the future forearc constructed?}

In a mature subduction, a forearc corresponds to the area between the trench and the magmatic arc and represents the leading edge of the supra-subduction plate. Although forearcs may be complex, often with multiple episodes of volcanism (Shervais, 2001; Meffre et al., 2012), most forearc lavas are among the earliest products in any given subduction zone (Mitchell et al., 1992; Ishizuka et al., 2006, 2011, 2018; Reagan et al., 2017). This suggests that the forearc basement is predominantly built during subduction infancy by near-trench magmatism (Reagan et al., 2010; Ishizuka et al., 2011; Reagan et al., 2017).

The M\&H area is a modern analog of this specific stage of the building of the future forearc. It is characterized today by a juxtaposition of several contrasted domains, such as the highstanding blocks in the Hunter Ridge, the Eissen Spreading Center and the Monzier Rift. These contrasted domains have different origins. The high-standing blocks in the Hunter Ridge probably represent dismembered remnants of the 10 Ma old Vitiaz Arc, while the Eissen Spreading Center and Monzier Rift opened since 2 Ma, synchronously with the subduction initiation.

To distinguish settings directly related to the subduction initiation, we propose the term Subduction Initiation Terrane (SITER). SITERs, besides being of an age corresponding to the early history of one subduction zone, should be distinguished by the very diverse compositional range of their magmas, reflecting the presence of two components, an asthenospheric derived MORB-like decompression melt and a slab melt, and their mixing products, including adakites. Based on these proposed characteristics, the Monzier Rift is clearly a SITER, whereas the Eissen Spreading Center, although formed synchronously with the subduction initiation, is not a SITER as, based on our current sampling of magma products, this domain has erupted only BABB-like compositions.

Finally, today, the proto-forearc of the $\mathrm{M} \& \mathrm{H}$ subduction zone is a collage of SITERs, coeval domains of back-arc type oceanic crust and remnants of pre-existing terranes including old Vitiaz Arc crust. As the subduction matures, we speculate that the proto-forearc will likely see the progressive addition of small amounts of arc tholeiites and calc-alkaline rocks before being fossilized as the volcanism will definitely back away from the trench and stabilize under the future arc.

This juxtaposition of SITERs with other contrasted terranes is a direct consequence of the subduction initiation. We interpret it as a very generic feature that should characterize most forearcs, regardless of their present location, in situ at the front of mature subduction zones, or in SSZ ophiolites. 


\section{Conclusion}

As the 2 Ma old M\&H subduction zone corresponds to the youngest known volcanically-active subduction system, it provides much needed insights into the nature of magmatism at the initiation of a subduction zone.

Lavas from the $\mathrm{M} \& \mathrm{H}$ area show an exceptionally diverse range of compositions. They suggest melting of upwelling asthenospheric mantle (Indian MORB) and subducted oceanic crust (Pacific MORB of the South Fiji Basin) and the mixing of these two components.

From its geochemical, geodynamic, chronological and geomorphological features we demonstrate the $\mathrm{M} \& \mathrm{H}$ subduction zone is an infant subduction system which has evolved to the first stage of magmatism. This early stage corresponds to pre-arc, near-trench magmatism building what we call Subduction Initiation Terranes (SITERs) in the proto-forearc of an immature subduction zone. As a consequence of the tectonic setting of subduction initiation, such SITERs are characterized by a very diverse compositional range of their magmas, reflecting the presence of two components, an asthenospheric derived MORB-like decompression melt and a slab melt, and their mixing products, including adakites.

Such SITERs, together with coeval back-arc domains and remnants of old Vitiaz Arc crust, make up the current proto-forearc of the $\mathrm{M} \& \mathrm{H}$ subduction zone. We speculate that, as the subduction zone matures, the magmatism will move away from the trench, eventually leaving the near trench area stranded. From then on, the proto-forearc will remain practically unmodified. Therefore, the future forearc of the subduction zone, once mature, will be a juxtaposition of SITERs with domains of back-arc type oceanic crust and remnants of preexisting terranes including old Vitiaz Arc crust. We interpret this, the SITER and its juxtaposition with contrasted terranes, as a very generic setting that should characterize most forearcs, regardless of their present location, in situ at the front of mature subduction zones, or in SSZ ophiolites.

Is the $\mathrm{M} \& \mathrm{H}$ a pertinent modern analog of subduction initiation and immature forearc formation? Having formed from the collision of an ancient STEP fault with the Loyalty Ridge at the location of a spreading ridge (Fig. 1; see also Wortel et al., 2009; Patriat et al., 2015; Maillet et al., 1989), the M\&H may be considered too complex and specific. However, analog and numerical modeling demonstrates that it is difficult to initiate subduction from simpler settings (Gurnis et al., 2004; Stern \& Gerya, 2018), suggesting that the geodynamic and petrological complexity observed at the $\mathrm{M} \& \mathrm{H}$ may indeed be a prerequisite for the development of a mature modern oceanic subduction system.

Finally, the M\&H area constitutes the only known modern analog of the Supra Subduction Zone environment at the initiation of a subduction zone. Therefore, knowledge from the M\&H area brings valuable insights into the genesis of ophiolites, a majority of which have been considered to have inherited their lithosphere from such a setting.

\section{Acknowledgements}

This work was supported by the Australian Marine National Facility through funding to three research voyages of the R/V Southern Surveyor (SS10/2004, SS08/2006, and SS03/2009; Danyushevsky and Falloon Principal Investigators); by the Australian Research Council through funding to CODES, the ARC Centre of Excellence in Ore Deposits; and by the Marine Geosciences Research Agreement between the Government of New Caledonia and Ifremer. We thank Katie McGoldrick, Phil Roberston, Sarah Gilbert, Jay Thompson and Stephen Eggins for their help with obtaining geochemical analyses. Formal reviews by Julian Pearce and an 
anonymous reviewer, as well as comments from the Editor Tamsin Mather, significantly improved this paper.

\section{References}

Arculus, R.J., Ishizuka, O., Bogus, K.A., Gurnis, M., Hickey-Vargas, R., Aljahdali, M.H., Bandini-Maeder, A.N., Barth, A.P., Brandl, P.A., Drab, L., do Monte Guerra, R., Hamada, M., Jiang, F., Kanayama, K., Kender, S., Kusano, Y., Li, H., Loudin, L.C., Maffione, M., Marsaglia, K.M., McCarthy, A., Meffre, S., Morris, A., Neuhaus, M., Savov, I.P., Sena, C., Tepley III, F.J., van der Land, C., Yogodzinski, G.M., Zhang, Z., 2015. A record of spontaneous subduction initiation in the Izu-Bonin-Mariana arc. Nat. Geosci.8, 728-733. http://dx.doi.org/10.1038/NGEO2515.

Bloomer, S.H., Ewart, W., Hergt, J.M., and Bryant, W.T., 1994, Geochemistry of igneous rocks from ODP Site 841, Tonga forearc, in Hawkins, J.W., Parsons, L., Allan, J., et al., Proceedings of the Ocean Drilling Program, Scientific Results Volume 135: College Station, Texas, Ocean Drilling Program, p. 625-646.

Bloomer, S.H., Taylor, B., MacLeod, C.J., Stern, R.J., Fryer, P., Hawkins, J.W., and Johnson, L., 1995, Early arc volcanism and the ophiolite problem: A perspective from drilling in the western Pacific, in Taylor, B., and Natland, J., eds., Active Margins and Marginal Basins of the Western Pacific: American Geophysical Union Geophysical Monograph 88, p. 1-30.

Calmant, S., B. Pelletier, P. Lebellegard, M. Bevis, F. W. Taylor, and D. A. Phillips (2003), New insights on the tectonics along the New Hebrides subduction zone based on GPS results, J. Geophys. Res., 108(B6), 2319, doi: 10.1029/2001JB000644.

Crawford, A. J., T. J. Falloon, and D. H. Green, 1989. Classification, petrogenesis, and tectonic setting of boninites, in Boninites and Related Rocks, edited by A. J. Crawford, pp. 1-49, Unwin Hyman, Boston, Mass..

Danyushevsky, L. V., A. J. Crawford, R. L. Leslie, S. Tetroeva, and T. J. Falloon (2006), Subduction-related magmatism along the southeast margin of the North Fiji back-arc basin, Geochem. Cosmochim. Acta, 69(10), A633.

Danyushevsky L.V., Falloon T.J., Crawford A.J., Sofia A.T., Leslie R.L., Verbeeten, A., 2008. High-Mg adakites from Kadavu Island Group, Fiji, Southwest Pacific: Evidence for the mantle origin of adakite parental melts. Geology, 36, 6, 499-502. doi: 10.1130/G24349A.1

Deschamps A. and Lallemand S., 2003. Geodynamic setting of Izu-Bonin-Mariana boninites. In: Intra-Oceanic Subduction Systems: Tectonic and Magmatic Processes, Eds: Larter, R.D. \& Leat, P.T., Geological Society, London, Special Publications, 219, 163-185.

Durance, P. M. J., M. A. Jadamec, T. J. Falloon, and I. A. Nicholls (2012), Magmagenesis within the Hunter Ridge Rift Zone resolved from olivine-hosted melt inclusions and geochemical modelling with insights from geodynamic models, Aust. J. Earth Sci., 59(6), 913-931.

Falloon, T. J., Danyushevsky, L. V., Crawford, A. J., Meffre, S., Woodhead, J. D. \& Bloomer, S. H. (2008). Boninites and adakites from the northern termination of the Tonga Trench: implications for adakite petrogenesis. Journal of Petrology 49(4) ,697-715.

Fleutelot C., Eissen J.-P., Dosso, L., Juteau, T., Launeau, P., Bollinger, C., Cotton, J., Danyushevsky, L., and Savoyant, L., 2005. Petrogenetic variability along the North-South propagating spreading center of the North Fiji Basin. Mineralogy and Petrology, 83, 55-86.

Gill, J., 1987. Early geochemical evolution of an oceanic island arc and back arc: Fiji and the South Fiji Basin. Journal of Geology, 95, 589-615.

Govers, R., and M. J. R. Wortel (2005), Lithosphere tearing at STEP faults: Response to edges of subduction zones, Earth Planet. Sci. Lett., 236, 505-523.

Gurnis, M., C. Hall, and L. Lavier (2004), Evolving force balance during incipient subduction, Geochem. Geophys. Geosyst., 5, Q07001, doi:10.1029/2003GC000681. 
Hanan, B.B., Blichert-Toft, J., Pyle, D.G., Christie, D.M., 2004. Contrasting origins of the upper mantle revealed by hafnium and lead isotopes from the Southeast Indian Ridge. Nature, 432, 91-94.

Hart, S. R., 1984. A large-scale isotope anomaly in the Southern Hemisphere mantle. Nature 309, 753-757.

Hickey-Vargas, R., Yogodzinski, G.M., Ishizuka, O., McCarthy, A., Bizimis, M., Kusano, Y., Savov, I.P., Arculus, R., 2018. Origin of depleted basalts during subduction initiation and early development of the Izu-Bonin-Mariana island arc: Evidence from IODP expedition 351 site U1438, Amami-Sankaku basin. Geochimica et Cosmochimica Acta, 229, 85-111.

Ishizuka, O., Kimura, J.-I., Li, Y.B., Stern, R.J., Reagan, M., Taylor, R.N., Ohara, Y., Bloomer, S.H., Ishii, T., Hargrove, U.S., III, and Haraguchi, S., 2006, Early stages in the evolution of Izu-Bonin arc volcanism: New age, chemical, and isotopic constraints: Earth and Planetary Science Letters, v. 250, p. 385-401, doi:10.1016/j.eps1.2006.08.007.

Ishizuka, O., Tani, K., Reagan, M.K., Kanayama, K., Umino, S., Harigane, Y., Sakamoto, I., Miyajima, Y., Yuasa, M., and Dunkley, D.J., 2011, The timescales of subduction initiation and subsequent evolution of an oceanic island arc: Earth and Planetary Science Letters, v. 306, p. 229-240, doi:10.1016/j.epsl.2011.04.006.

Ishizuka O., R. Hickey-Vargas, R.J. Arculus, G.M. Yogodzinski, Y. Kusano, A. McCarthy, I.P. Savov, M. Sudo, 2018. Age of Izu-Bonin-Mariana arc basement. Earth Planet Sci. Lett., v.481, pp80-90, doi:10.1016/j.eps1.2017.10.023

Jean, M.M. and Shervais, J.W., The distribution of fluid mobile and other incompatible trace elements in orthopyroxene from mantle wedge peridotites, Chem. Geol. (2017), http://dx.doi.org/10.1016/j.chemgeo.2017.03.017

Kelemen, P. B.; Hanghøj, K.; Greene, A. R., 2003. One View of the Geochemistry of Subduction-related Magmatic Arcs, with an Emphasis on Primitive Andesite and Lower CrustTreatise on Geochemistry, Volume 3. Editor: Roberta L. Rudnick. Executive Editors: Heinrich D. Holland and Karl K. Turekian, p.593-659, doi:10.1016/B0-08-0437516/03035-8

Lallemand S., 2016. Philippine sea plate inception, evolution and consumption with special emphasis on the early stage of Izu-Bonin-Mariana subduction. Prog. Earth Planet Sci., 3, 15, doi:10.1186/s40645-016-0085-6

Li, Y. B., Kimura, J. I., Machida, S., Ishii, T., Ishiwatari, A., Maruyama, S., Qiu, H. N., Ishikawa, T., Kato, Y., Haraguchi, S., Takahata, N., Hirahara, Y., and Miyazaki, T.: High-Mg adakite and low-Ca boninite from a bonin fore-arc seamount: Implications for the reaction between slab melts and depleted mantle, J. Petrol., 54, 1149-1175, https://doi.org/10.1093/petrology/egt008, 2013.

Lister, G. S., L. T. White, S. Hart, and M. A. Forster (2012), Ripping and tearing the rollingback New Hebrides slab, Aust. J. Earth Sci., 59(6), 899-911.

Maillet, P., M. Monzier, J. P. Eissen, and R. Louat (1989), Geodynamics of an arc ridge junction: The case of the New Hebrides Arc/North Fiji Basin, Tectonophysics, 165, 251268.

Meffre, S., T. J. Falloon, T. J. Crawford, K. Hoernle, F. Hauff, R. A. Duncan, S. H. Bloomer, and D. J. Wright (2012), Basalts erupted along the Tongan fore arc during subduction initiation: Evidence from geochronology of dredged rocks from the Tonga fore arc and trench, Geochem. Geophys. Geosyst., 13, Q12003, doi:10.1029/2012GC004335.

Mitchell J.G., D.W. Peate, B.J. Murton, J.A. Pearce, R.J. Arculus, and S. van der Laan (1992). K-Ar Dating of Samples from Sites 782 and 786 (Leg 125): The Izu-Bonin Forearc Region, in Fryer, P., et al., Proceeding of the Ocean Drilling Program, Scientific Results, Site 778786, Bonin-Mariana Region: College Station, Texas, Ocean Drilling Program, 203-210. doi:10.2973/odp.proc.sr.125.136.1992 
Monzier, M., P. Maillet, J. Foyo Herrera, R. Louat, F. Missegue, and B. Pontoise (1984), The termination of the southern New Hebrides subduction zone (southwestern Pacific), Tectonophysics, 101, 177-184.

Monzier M., Danyushevsky L. V., Crawford A. J., Bellon H. \& Cotten J. 1993. High-Mg andesites from the southern termination of the New Hebrides island arc (SW Pacific). Journal of Volcanology and Geothermal Research 57, 193-217.

Mortimer, N., Gans, P. B., Foley, F. V., Turner, M. B., Daczko, N., Robertson, M., \& Turnbull, I. M., 2013. Geology and age of Solander Volcano, Fiordland, New Zealand. Journal of Geology, 121(5), 475-487. DOI: 10.1086/671397

Patriat, M., J. Collot, L. Danyushevsky, M. Fabre, S. Meffre, T. Falloon, P. Rouillard, B. Pelletier, M. Roach, and M. Fournier (2015), Propagation of back-arc extension into the arc lithosphere in the southern New Hebrides volcanic arc, Geochem. Geophys. Geosyst., 16, 3142-3159, doi:10.1002/2015GC005717.

Pearce, J.A., Vander Laan, S.R., Arculus, R.J., Murton, B.J., Ishii, T., Peate, D.W., and Parkinson, I.J., 1992, Boninite and harzburgite from Leg 125 (Bonin-Mariana forearc): A case study of magma genesis during the initial stages of subduction, in Fryer, P., et al., Proceeding of the Ocean Drilling Program, Scientific Results, Site 778-786, Bonin-Mariana Region: College Station, Texas, Ocean Drilling Program, p. 623-659. doi:10.2973/odp.proc.sr.125.172.1992

Pearce JA, Lippard SJ, and Roberts S (1984) Characteristics and tectonic significance of suprasubduction zone ophiolites. In: Kokelaar P, Howells M (eds) Geology of marginal basins. Geological Society of London Special Publication 16, pp 77-94

Pearce, J.A., 2003, Supra-subduction zone ophiolites: The search for modern analogues, in Dilek, Y., and Newcomb, S., eds., Ophiolite concept and the evolution of geological thought: Boulder, Colorado, Geological Society of America Special Paper 373, p. 269-293.

Pearce, J.A., Kempton, P.D., and Gill, J.B., 2007. Hf-Nd evidence for the origin and distribution of mantle domains in the SW Pacific. Earth and Planetary Science Letters, 260, 98-114.

Peccerillo A., Taylor, S.R., 1976. Geochemistry of Eocene calc-alkaline volcanic rocks from the Kastamonu area, Northern Turkey. Contributions to Mineralogy and Petrology, 58, 6381.

Pushchin I.K., 1990. Preliminary report on the results of Geoscience Research in the New Hebrides Arc-Trench tectonic system (RV Akademik Alexander Nesmeyanov, Cruise 17), Pacific Oceanological Institute of the Far Eastern Branch of the USSR Academy of Sciences, SOPAC Cruise Report 134.

Reagan, M. K., Ishizuka O., Stern R. J., et al., 2010. Fore-arc basalts and subduction initiation in the Izu-Bonin-Mariana system, Geochem. Geophys. Geosyst., 11, Q03X12, doi:10.1029/2009GC002871

Reagan, M.K., McClelland, W.C., Girard, G., Goff, K.R., Peate, D.W., Ohara, Y., and Stern, R.J., 2013, The geology of the southern Mariana fore-arc crust: Implications for the scale of Eocene volcanism in the western Pacific: Earth and Planetary Science Letters, 380, 4151. 10.1016/j.epsl.2013.08.013.

Reagan M.K., Pearce J.A., Petronotis K., et al., 2017. Subduction initiation and ophiolite crust: new insights from IODP drilling, International Geology Review, DOI:10.1080/00206814.2016.1276482

Reay, A., Parkinson, D., 1997. Adakites from Solander Island, New Zealand. J. Geol. Geophys. 40, 121-126.

Ribeiro, J., Stern, R.J., Kelley, K., Martinez, F., Ishizuka, O., Manton, W.I., Ohara, Y., 2013. Nature and distribution of the slab-derived fluids and the mantle source along the Southeast Mariana Forearc Rift. Geochem. Geophys. Geosyst.14 (10), 4585-4607. http://dx.doi.org/10.1002/ggge.20244. 
Ribeiro, J., Stern, R.J., Martinez, F., Ishizuka, O., Merle, S.G., Kelley, K.A., Anthony, E.Y., Ren, M., Ohara, Y., Reagan, M., Girard, G., Bloomer, S.H., 2013b. Geodynamic evolution of a forearc rift in the southernmost Mariana Arc. Isl. Arc22, 453-476.

Shervais, J.W., 1982. Ti-V plots and the petrogenesis of modern and ophiolitic lavas: Earth and Planetary Science Letters, v. 59, p. 101-118.

Shervais, J.W., 2001. Birth, death, and resurrection: The life cycle of suprasubduction zone ophiolites, Geochem. Geophys. Geosyst., vol. 2, doi: 10.1029/2000GC000080.

Sigurdsson, I. A., V. S. Kamenetsky, A. J. Crawford, S. M. Eggins, and S. K. Zlobin (1993), Primitive island arc and oceanic lavas from the Hunter Ridge-Hunter Fracture Zone. Evidence from glass, olivine and spinel compositions, Mineral. Petrol., 47, 149-169.

Stern, R.J., 2004, Subduction initiation: Spontaneous and induced: Earth and Planetary Science Letters, v. 226, p. 275-292.

Stern, R.J., and Bloomer, S.H., 1992, Subduction zone infancy: Examples from the Eocene IzuBonin-Mariana and Jurassic California arcs: Geological Society of America Bulletin, v. 104, p. 1621-1636, doi:10.1130/0016- 7606

Stern R. J., M. Reagan, O. Ishizuka, Y. Ohara, S. Whattam, 2012. To understand subduction initiation, study forearc crust: To understand forearc crust, study ophiolites. Lithosphere; 4 (6): 469-483. doi: https://doi.org/10.1130/L183.1

Stern, R.J. and Gerya T., 2018. Subduction initiation in nature and models: A review. Tectonophysics, http://dx.doi.org/10.1016/j.tecto.2017.10.014

Sun, S.S., McDonough, W.F., 1989. Chemical and isotopic systematics of oceanic basalts: implications for mantle composition and processes. In: Saunders, A.D., Norry, M.J. (Eds.), Magmatism in the Ocean Basins. Geological Society Special, Publication, 42, pp. 313-345.

Sutherland, R., Barnes, P., Uruski, C., 2006. Miocene-Recent deformation, surface elevation, and volcanic intrusion of the overriding plate during subduction initiation, offshore southern Fiordland, Puysegur margin, southwest New Zealand. N. Z. J. Geol. Geophys. 49, 131-149.

Syracuse E.M. \& Abers G.A. (2006). Global compilation of slab depth beneath arc volcanoes and implications. Geochem., Geophys., Geosyst., 7, doi: 10.1029/2005GC001045.

Tatsumi, Y., and S. Eggins, Subduction Zone Magmatism, Blackwell, Malden, Mass., 1995.

Taylor, S.R., Gorton, M.P., 1977. Geochemical application of spark source mass spectrography III. Element sensitivity, precision and accuracy. Geochim. Cosmochim. Acta 41, 13751380.

Whattam, S.A., and Stern, R.J., 2011, The 'subduction-initiation rule': A key for linking ophiolites, intra-oceanic forearcs and subduction initiation: Contributions to Mineralogy and Petrology, v. 162, p. 1031-1045, doi:10.1007/s00410-011-0638-z.

Wortel, M., R. Govers, and W. Spakman (2009), Continental collision and the STEP-wise evolution of convergent plate boundaries: From structure to dynamics, in Subduction Zone Geodynamics, edited by S. Lallemand and F. Funiciello, pp. 47-59, Springer, SpringerVerlag, Berlin Heidelberg. 